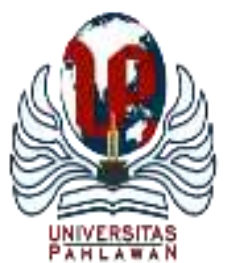

Edukatif : Jurnal Ilmu Pendidikan Volume 3 Nomor 5 Tahun 2021 Halm 3350 - 3360

EDUKATIF: JURNAL ILMU PENDIDIKAN

Research \& Learning in Education

https://edukatif.org/index.php/edukatif/index

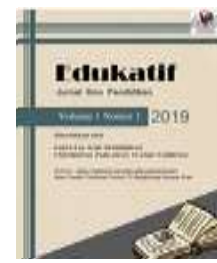

\title{
Analisis Tindak Tutur pada Film Riko The Series (Kajian Pragmatik) melalui Teks, Ko-teks, dan Konteks
}

\author{
Foottriani Azziz $^{1 凶}$, Suntoko $^{2}$, Wienike Dinar Pratiwi ${ }^{3}$ \\ Pendidikan Bahasa dan Sastra Indonesia, Universitas Singaperbangsa Karawang 1,2,3 \\ E-mail : 1710631080066@ student.unsika.ac.id ${ }^{1}$, suntoko@ @kip.unsika.ac.id ${ }^{2}$, \\ wienike.dinar@ fkip.unsika.ac.id ${ }^{3}$
}

\begin{abstract}
Abstrak
Rendahnya pengetahuan dan pemahaman pembelajar terhadap tindak tutur dalam kegiatan komunikasi, sehingga penelitian ini bertujuan untuk memberi penjelasan hakikat sebuah tuturan dari seorang penutur. Penelitian ini merupakan pengungkapan tindak tutur yang ada pada sebuah film animasi Indonesia. Subjek penelitian berupa film animasi Riko The Series pada aplikasi Youtube. Data yang digunakan sebanyak delapan episode dengan pemilihan secara acak. Penelitian menggunakan pendekatan deskriptif kualitatif. Pengumpulan data dilakukan melalui tahap simak dan catat untuk memudahkan proses analisis. Penelitian ini menggunakan teknik simak bebas libat cakap. Penelitian ini bertujuan untuk mengidentifikasi teks, ko-teks, konteks guna mengetahui pemakaian bentuk tindak tutur yang ada dalam film Riko The Series. Selain itu, penelitian ini Teknik analisis data mengacu pada teori Hymes yang meliputi S.P.E.A.K.I.N.G, yaitu Setting (Latar), Participants (peserta), Ends (Tujuan), Act Sequences (Alur), Key (Kunci), Instrumentalities (sarana), Norms (norma), dan Genre (jenis). Dalam penelitian ini diperoleh hasil 326 teks, 295 ko-teks, 52 konteks, dan 76 bentuk tindak tutur yang meliputi Asertif, Direktif, Komisif, Ekspresif.
\end{abstract}

Kata Kunci: Tindak Tutur, Konteks, Film.

\begin{abstract}
The low knowledge and understanding of learners towards speech acts in communication activities, so this study aims to provide an explanation of the nature of an utterance from a speaker. This research is a disclosure of speech acts in an Indonesian animated film. The research subject is the animated film Riko The Series on the Youtube application. The data used are eight episodes with random selection. The study used a qualitative descriptive approach. Data collection was carried out through the read and note stage to facilitate the analysis process. This study uses the free-of-conversation listening technique.This study aims to identify the text, co-text, context in order to determine the use of speech acts in the Riko The Series film. In addition, this research data analysis technique refers to the theory of Hymes which includes SPEAKING, namely Settings (background), Participants (participants), Ends (Goals), Act Sequences (Flow), Key (Kenk), Instrumentalities (means of ), Norms (norms), and Genres (types). In this study, the results obtained 326 texts, 295 co-texts, 52 contexts, and 76 forms of speech acts which include Assertive, Directive, Commissive, Expressive.
\end{abstract}

Keywords: speach act, context, film.

Copyright (c) 2021 Foottriani Azziz, Suntoko, Wienike Dinar Pratiwi

$\triangle$ Corresponding author

Email : 1710631080066@student.unsika.ac.id

DOI : https://doi.org/10.31004/edukatif.v3i5.1302

ISSN 2656-8063 (Media Cetak)

ISSN 2656-8071 (Media Online)

Edukatif : Jurnal Ilmu Pendidikan Vol 3 No 5 Tahun 2021 p-ISSN 2656-8063 e-ISSN 2656-8071 
3351 Analisis Tindak Tutur pada Film Riko The Series (Kajian Pragmatik) melalui Teks, Ko-teks, dan Konteks Foottriani Azziz, Suntoko, Wienike Dinar Pratiwi

DOI: https://doi.org/10.31004/edukatif.v3i5.1302

\section{PENDAHULUAN}

Pembatasan sosial berskala besar yang berlaku semenjak pandemi Covid menghantui Indonesia, mengubah masyarakat jadi lebih berhati-hati keluar rumah. Bioskop tempat kaum milenial nongkrong diharuskan tutup sementara waktu, hal ini membuat segelintir masyarakat beralih ke sambungan internet dalam berkomunikasi. Meski demikian situasi tak menghambatnya, masyarakat tetap bisa saling berinteraksi dengan teman, kerabat, saudara, hingga kenalan sekalipun. Media sosial menjadi solusi yang tepat dalam mengatasi situasi pandemi. Yakni sebagai sarana penghubung interaksi yang terjalin antar seseorang atau sekumpulan orang dalam partisipasinya di kegiatan-kegiatan sosial.

Berdasarkan data persentase Hootsuite dan We Are Social penggunaan media sosial di dunia, pertahun 2021 Youtube menduduki urutan kedua setelah Facebook dan dinobatkan sebagai media sosial terpopuler di Indonesia kalangan usia 16-24. Hal tersebut membuktikan bahwa Platform Youtube menjadi aplikasi paling dominan semenjak pandemi melanda Indonesia. Hal ini membuat segelintir masyarakat meramaikan akun Youtube pribadinya sebagai ajang menambah penghasilan ditengah krisisnya ekonomi. Kini dunia seni semakin bertambah kreator muda berlomba-lomba menghasilkan karya terbaiknya demi meraih eksistensi. Berkat hal tersebut, Youtube berhasil menarik perhatian peneliti untuk memanfaatkan film Riko The Series sebagai penunjang penelitian ini.

Semakin majunya zaman, sebuah tontonan sangat mempengaruhi karakteristik yang dibangun pada seorang anak. Selaras dengan penelitian yang dikemukakan oleh (Kurnia \& Solfiah, 2018) bahwa tontonan anak juga berpengaruh terhadap kualitas menulis anak. Seperti pensil karakter animasi Upin \& Ipin yang merangsang kemampuan menulis anak cenderung lebih semangat jika dibandingkan dengan pensil polos. Semangat menulis anak ada pada gambar karakter alat tulisnya. Hasil yang diperoleh membuktikan bahwa terdapat pengaruh yang signifikan pada penggunaan media pensil karakter terhadap hasil belajar anak. Peserta didik lebih rajin mengumpulkan tugas semenjak menggunakan pensil bergambar dibanding pensil tanpa gambar.

Begitupun dengan hasil testimoni masyarakat mengenai beragamnya komentar positif menjadi salah satu alasan kuat peneliti memilih film Riko The Series. Hal tersebut diungkapkan dalam penelitian (Rahmayanti et al., 2021) bahwa film Riko The Series mampu menjadikan media pembelajaran sebagai penguatan pendidikan karakter anak. Konsep edukasi yang di pakai dalam film bisa lebih menarik proses pembelajaran berlangsung. Mengingat anak sering meniru hal yang dilihatnya, pendidik ataupun orang tua bisa memperkenalkan film animasi tersebut sebagai sarana edukasi dalam bentuk hiburan. Tidak cukup menghibur saja, kesuksesan sebuah hiburan yang berkualitas tentu ternilai dari kebermanfaatan yang terlihat. Baik dari sisi pengamat juga penikmatnya. Film Riko The Series mempunyai nilai tambahan dari adanya unsur edukatif yang dibangun berdasarkan ajaran Agama Islam juga Ilmu Pengetahuan (Sains) sengaja dilibatkan.

Inilah keunggulan film tersebut dibandingkan dengan animasi Indonesia lainnya seperti Adit dan Sopo Jarwo, Juki The Movie, dan lain-lain yang masih eksis. Animasi ini menjadi sarana bagi anak-anak dalam mengeksplor rasa ingin tahu terhadap ilmu pengetahuan. Sebab film animasi ini sengaja diciptakan dengan tujuan memberi wawasan ilmu pengetahuan (Sains) dengan metode cerita petualangan yang dekat dengan kehidupan sehari-hari. Melalui konflik yang dibangun pemakaian bahasa dipilih seringan mungkin, hal ini agar lebih mudah dipahami oleh penonton anak.

Selain itu, film Riko The Series berhasil memberi contoh dalam berbusana rapih jelas ditampilkan pada pakaian yang dikenakan tiap karakternya. Bunda dan Kak Wulan memakai busana yang sopan dalam situasi apapun dan dimanapun. Lengkap dengan balutan kain menutup bagian kepala, keduanya tampil cantik layaknya seorang muslimah. Penampilan tersebut secara tak langsung seolah memberi gambaran bagi muslimah untuk selalu menjaga auratnya melalui busana yang dipakai. 
Ditengah meroketnya era digital saat ini, menuntut peran orang tua untuk lebih cermat dalam memberikan sebuah tontonan pada anaknya. Selain motivasi yang dibangun dalam membangkitkan minat belajar, pendamping siswa perlu menyaring tontonan yang layak konsumsi bagi anak usianya. Hal tersebut terbukti dalam penelitian (Achsani, 2019). Begitu pentingnya peran orang tua untuk bijak dalam mengontrol input yang akan diterima dan diserap oleh memori anak.

Film genre islami ini telah eksis sejak tahun 2020 yang berhasil mengunggah tayangan perdananya pada 9 Februari. Pendiri kanal Youtube Riko The Series didirikan oleh aktor Indonesia yang bernama Teuku Wisnu, Arie Untung, dan Yuda Wirafianto juga dibantu bersama mahasiswa ITB. Tujuan dibuatnya film tersebut dapat meningkatkan keingintahuan dan menambah pengetahuan anak. Karena dengan tampilan animasi, diyakini penyampaian amanat dapat lebih mudah diingat bagi penontonnya.

Ilmu kebahasaan sangat penting dalam kehidupan sosial. Sama halnya dengan masyarakat yang memerlukan bahasa untuk membentuk proses interaksi antar individu. Bahasa sebagai alat penyampai pesan antara penutur dengan mitra tutur baik secara lisan maupun tulisan. Dalam penggunaannya, perlu adanya pemahaman tindak tutur dalam berkomunikasi. Pemahaman yang baik mengenai beragamnya bentuk tuturan yang ada akan memudahkan kelancaran interaksi dengan mitra tutur. Selaras dengan penelitian (Asriningsih, 2020) yang mengungkapkan bahwa keberhasilan tuturan seseorang dalam mencapai tujuannya dilihat dari kesesuaian konteks. Hanya jenis tindak ilokusi dan perlokusi yang memerlukan keterlibatan konteks. Jadi, untuk memahami arah tuturan harus melalui pemahaman konteks yang melibatkannya.

Data yang akan dianalisis masih berupa dialog yang berlangsung di film Riko The Series pada episode Tolooong, Astaghfirullah Aku Lupa!, Pantang Menyerah, Pagi yang Indah, Hujan, Jangan Marah, Ayo Tumbuh ke Atas!, Lebih Baik Memaafkan yang ada pada Season 01-02 yang nantinya akan ditranskrip terlebih dahulu ke dalam bentuk tulisan. Melalui dialog percakapan antar tokoh, pesan/maksud yang hendak dituju akan berhasil sesuai latar belakang pemahaman penutur dan mitra tutur dalam membangun sebuah tuturan. Dengan demikian, begitu pentingnya memiliki pemahaman yang baik terhadap konteks.mengenai bagaimana cara seseorang bisa menafsirkan sebuah tuturan.

Berdasarkan pentingnya pemahaman konteks dalam komunikasi, penelitian ini akan fokus pada pengungkapan maksud yang ada pada dialog karakter film Riko The Series melalui analisis teks, koteks, konteks sesuai latar belakang sebuah tuturan. Pengungkapan konteks sebuah tuturan dituju untuk mempermudah dalam tahap klasifikasi pada beberapa macam bentuk dan fungsi tindak tutur. Klasifikasi bentuk tindak tutur berdasarkan teori Searle (Prayitno, 2017) yang membagi ke dalam lima macam tuturan. Bentuk asertif (representatif), direktif, komisif, ekspresif, deklaratif. Tujuan dari dibuatnya penelitian ini agar dapat memahami maksud setiap tuturan yang hendak disampaikan oleh penutur serta tercipta komunikasi yang searah dan saling berkesinambungan.

Pembeda yang membuat penelitian ini lain dengan penelitian terdahulu yaitu ada pada langkah analisis yang digunakan. Penelitian ini melalui tahap pengamatan teks, koteks, konteks terlebih dahulu untuk mengungkap maksud yang sesungguhnya. Sesuai arti yang dijabarkan dari sebuah tuturan, macam-macam bentuk tuturan yang dipakai akan terlihat jelas sesuai data. Lain halnya dengan penelitian tindak tutur yang dilakukan oleh (Rahma, 2018) yang mengungkapkan makna percakapan tanpa menggunakan analisis konteks terlebih dahulu untuk menentukan klasifikasi bentuk tuturan.

\section{METODE PENELITIAN}

Berdasarkan penelitian, metode yang digunakan pada penelitian ini yaitu metode kualitatif. Pemilihan metode ini berdasarkan karakteristik tujuan penelitian yang dilakukan. Sesuai dengan pernyataan (Sugiyono, 2018) bahwa metode penelitian kualitatif adalah metode penelitian yang digunakan untuk meneliti pada kondisi objek yang bersifat alamiah. Metode ini dipakai agar tujuan penelitian tercapai sesuai dengan prosedur 
yang telah dirancang dalam penelitian. Dalam penelitian ini juga menggunakan metode deskriptif. Deskriptif yang digunakan pada penelitian ini sesuai dengan ungkapan (Arikunto, 2013) bahwa penelitian deskriptif yaitu penelitian yang dimaksudkan untuk mengumpulkan informasi mengenai status suatu gejala yang ada, keadaan gejala menurut apa adanya pada saat penelitian dilakukan. Penelitian ini tidak melibatkan lambang angka, sebab data yang diteliti berupa tuturan kata-kata. Dan pemecahan masalah dilakukan dengan menggambarkan hasil berdasarkan fakta yang sesuai apa adanya tanpa campur tangan persepsi individual. Sehingga hasil yang terkumpul akan tergambar jelas dan jauh dari ketidaksesuaian. Penelitian ini juga menggunakan pendekatan pragmatis dalam analisisnya, sebab masih masuk dalam jenis penelitian pada bahasa. Yakni pengungkapan makna yang berhubungan dengan situasi ujaran yang berlangsung pada percakapan tokoh film.

Sasaran penelitian ini ada pada pecakapan tokoh film Riko The Series yang dirangkai dalam sebuah adegan. Peneliti menggunakan delapan episode yang ada pada channel Youtube Riko The Series sebagai data analisis. Data yang dipilih secara acak ini meliputi, episode Tolooong, Astaghfirullah Aku Lupa, Pantang Menyerah, Pagi Yang Indah, Hujan, Jangan Marah, Ayo Tumbuh Ke Atas, Lebih Baik Memaafkan. Fokus penelitian tertuju pada tuturan yang digunakan tokoh dalam percakapan yang diperagakan oleh seluruh karakter. Pengumpulan data dilakukan dengan menggunakan teknik simak dan catat. Sesuai dengan ungkapan (Mahsun, 2014) mengenai metode simak adalah cara yang digunakan untuk memperoleh data dengan menyimak penggunaan bahasa. Teknik simak merupakan pilihan yang sangat tepat bagi kegiatan penelitian ini yang menggunakan aspek bahasa guna memperoleh data yang akan di selidiki hingga dapat menjawab masalahan penelitian. Dalam penelitian ini, peneliti tidak terlibat dalam kegiatan percakapan yang berlangsung pada subjek penelitian. Jadi peneliti hanya sebagai pengamat dan penyimak penggunaan bahasa yang diucapkan oleh tokoh film Riko The Series. Hal ini sesuai dengan pernyataan (Sudaryanto, 2015) bahwa seorang peneliti yang tidak terlibat dalam proses komunikasi, maka teknik yang digunakan adalah teknik bebas libat cakap.

Instrumen pada penelitian ini berasal dari keaktifan peneliti sebagai pengamat. (Moleong, 2016) menyatakan bahwa kedudukan peneliti dalam penelitian kualitatif adalah sebagai instrumen penelitian. Dengan menetapkan fokus penelitian, peneliti sendiri yang melakukan analisis, menilai, menafsirkan, hingga menarik kesimpulan dilakukan secara mandiri. Pada proses penelitian ini, peneliti berpedoman pada tiga tabel instrumen yaitu teks, ko-teks, dan konteks yang telah di rancang berdasarkan teori yang ada. Sebelum melalui tahap instrumen, data penelitian harus di dokumentasikan untuk kebutuhan analisis. Tahap dokumentasi dilakukan dengan cara mendownload film yang menjadi subjek penelitian. Alat dan bahan yang diperlukan saat pengumpulan data yaitu fasilitas gawai, aplikasi Youtube, dan sambungan internet.

\section{HASIL DAN PEMBAHASAN PENELITIAN}

Berdasarkan analisis data, berikut hasil penelitian. Dari total delapan episode Riko The Series, peneliti berhasil menemukan 326 buah dialog dengan 52 konteks tuturan. Dengan rincian sebagai berikut, Episode Tolooong; 5 konteks, Astaghfirullah Aku Lupa; 7 konteks, Pantang Menyerah; 10 konteks, Pagi Yang Indah; 5 konteks, Hujan; 6 konteks, Jangan Marah; 7 konteks, Ayo Tumbuh Ke Atas; 4 konteks, Lebih Baik Memaafkan; 8 konteks. Berdasarkan jumlah konteks dari delapan episode, peneliti menemukan ko-teks sebanyak 295. Pada penelitian ini, peneliti berhasil menemukan beberapa bentuk tindak tutur meliputi asertif sebanyak 20, direktif sebanyak 46, komisif sebanyak 4, ekspresif 6 , dan tidak ditemukannya bentuk deklaratif. Jumlah dari keempat bentuk tindak tutur yang terkumpul yaitu sebanyak 76 tuturan.

Pada episode Tolooong sebagai data pertama dalam penelitian ini terhitung ada 35 dialog yang melibatkan tokoh utama Riko, Qiio sebagai sahabatnya, tokoh Wulan sebagai kakaknya, tokoh Bunda sebagai ibu, dan tokoh Ayah. Episode ini berdurasi 8 menit 28 detik ada pada Season 02. Amanat yang ingin 
disampaikan pada episode ini yaitu informasi seputar gempa bumi dan apa yang harus dilakukan saat terjadi fenomena alam tersebut. Latar waktu yang digunakan pada episode tersebut berjumlah dua yaitu siang dan malam hari. Lima buah konteks yang terdapat dalam episode Tolooong meliputi 1) guncangan akuarium yang dihubungkan dengan fenomena alam gempa bumi, 2) menyelamatkan diri dari gempa bumi, 3) berkemah di halaman depan rumah, 4) persiapan bencana susulan, 5) perdebatan tempat tidur antara adik-kakak.

Konteks satu pada episode Tolooong terdiri dari bentuk tindak tutur direktif perintah, kritik, ekspresif dengan fungsi meminta maaf, dan asertif menggambarkan juga menjelaskan. Konteks ini letaknya ada pada menit 1:10 sampai 3:22 dengan jumlah 10 dialog yang melibatkan tokoh Riko, Qiio, dan kak Wulan. Dari 10 dialog tersebut terdiri dari 10 ko-teks. Konteks kedua pada episode tolong terdiri dari 6 dialog yang melibatkan tokoh Riko, Qiio, dan Bunda. Konteks ini ada pada menit 3:50 sampai 5:18, terdapat 6 buah koteks. Bentuk tindak tutur pada konteks ini berupa direktif ajakan, tokoh Qiio sebagai penutur dan Riko sebagai mitra tutur. Konteks ketiga pada episode tolong terdiri dari 6 dialog yang melibatkaan antara tokoh Ayah, Riko, dan Bunda. Konteks berada pada menit 5:38 sampai 6:10. Jenis tuturan yang digunakan adalah tuturan langsung sebab maksud tuturan langsung tersampaikan dengan jelas pada mitra tutur. Dalam konteks ini terdiri dari 6 ko-teks. Bentuk tindak tutur yang digunakan yaitu direktif permintaan yang dituturkan oleh tokoh Riko dan tokoh Bunda.

Bunda: nih. Semua perlengkapan kita, udah Bunda siapin di tas ini. Tas ini namanya, tas siaga bencana. insyaAllah cukup untuk keperluan kita selama tiga hari. Bunda sengaja taro di depan pintu supaya gampang ngambilnya.

Ayah : masyaAllah, Bunda keren banget si. Kebetulan Ayah juga ada aplikasi loh, inaRISK personal dari BNPB. Nah ini buat memantau situasi bencana. Kita bisa lihat posisi gempanya itu terjadi dimana, karena ada notifikasi info gempa. Terus, kita juga bisa tau, ditempat kita ini ada potensi apa lagi selain gempa. Selain itu, juga ada rekomendasi upaya yang dapat dilakukan sebelum, sesaat, dan setelah bencana.

Qiio : wah, inaRISK keren.

\section{Episode Tolooong}

$$
6: 16-6: 36
$$

Konteks tuturan tersebut dapat dijelaskan sebagai berikut. Kebutuhan siaga bencana yang praktis dan sangat bermanfaat telah disiapkan Bunda. Tuturan berlangsung pada malam hari di depan tenda yang pasang di halaman rumah. Ayah mengenalkan aplikasi pemantau bencana yang praktis hanya dengan bantuan gawai. Sedangkan Bunda mengenalkan tas siaga bencana yang disiapkan dekat pintu. Bentuk tuturan yang digunakan pada konteks tersebut yaitu tindak tutur asertif dengan maksud menginformasikan. Seperti tuturan Bunda dan Ayah pada konteks tersebut. Selain itu, ada bentuk tindak tutur ekspresif yang dituturkan oleh tokoh Qiio. Partisipan yang terlibat dalam konteks meliputi tokoh Ayah, Bunda, dan Qiio. Latar waktu menunjukkan malam hari di halaman rumah.Konteks keempat pada episode tolong terdiri dari tiga buah dialog yang melibatkan tokoh Bunda, Ayah, dan Qiio. Ko-teks berjumlah tiga, bentuk tindak tutur menggunakan asertif menjelaskan yang dituturkan oleh tokoh Ayah. Konteks ini berada pada menit 6:16 sampai 6:36. Konteks kelima yaitu perdebatan tempat tidur antara adik-kakak yang terdiri dari 6 dialog dengaan 6 ko-teks. Tokoh yang terlibat yaitu Riko, dan kak Wulan. Konteks ini berada di menit 7:15 sampai 7:42. Bentuk tindak tutur yang ada pada konteks meliputi direktif perintah dengan fungsi menyuruh. Tuturan tersebut ditandai oleh dialog tokoh kak Wulan dan Riko.

Pada episode Astaghfirullah Aku Lupa sebagai data kedua dalam penelitian ini terdiri dari 50 dialog yang melibatkan tokoh utama Riko, Qiio sebagai sahabatnya,tokoh Wulan sebagai kakaknya, tokoh Bunda sebagai ibu, dan tokoh Ayah. Episode ini berdurasi 8 menit 14 detik ada pada Season 02. Amanat yang ingin disampaikan pada episode ini yaitu untuk sennatiasa ingat kewajiban dan tidak lalai akan tanggung jawab. Latar waktu yang digunakan pada episode tersebut berjumlah tiga yaitu siang, sore dan malam hari. Konteks 
pada Episode Astaghfirullah Aku Lupa sebanyak 7 buah. Berikut uraian konteks yang ditemukan. 1) pengalaman lupa, 2) lomba balap mobil-mobilan, 3) kak Wulan mengingatkan PR Riko, 4) Qiio mengingatkan Riko, 5) Kak Wulan menagih janji Riko, 6) kelalaian Riko, 7) Bunda mengecek keadaan Riko. pada episode ini peneliti menemukan bentuk tindak tutur direktif sebanyak 10, meliputi fungsi mengingatkan, menyindir, memaksa,perintah, menasehati, permintaan.

Konteks pertama dalam episode ini perbincangan pengalaman lupa antara Riko dan Qiio. Durasi tercatat dari menit 0:33 sampai 0:49. Konteks ini terdiri dari 4 buah dialog dengan jumlah ko-teks yang sama. Tuturan berlangsung tanpa adanya latar waktu dan tempat. Sebab sepenggal konteks ini merupakan bagian pembukaan episode tersebut. Jadi, pada konteks ini tanpa menggunakan background. Konteks kedua pada episode ini melibatkan dua tokoh yaitu Riko dan Qiio. Durasi tercatat dari menit 1:24 sampai 1:34 dengan tiga buah dialog dan jumlah ko-teks yang sama. Tuturan terjadi pada siang hari di kamar Riko. keduanya tengah lomba balap mobil-mobilan. Konteks ketiga yaitu Wulan mengingatkab PR Riko yang terdiri dari 8 dialog dengan 6 buah ko-teks. Durasi tercatat dari menit 2:24 sampai 2:55. Tuturan terjadi di kamar Riko pada siang hari. Kak Wulan datang ke kamar Riko untuk mengingatkannya PR saat tengah asyik bermain. Bentuk tindak tutur yang digunakan yaitu direktif menyindir dan memaksa yang dituturkan oleh tokoh Wulan. Konteks keempat pada episode ini melibatkan tokoh Riko dan Qiio. Konteks ini terdapat bentuk tindak tutur direktif mengingatkan yang dituturkan oleh tokoh Qiio. Durasi tercatat dari menit 3:01 sampai 3:28. Terdiri dari 6 dialog dan jumlah ko-teks yang sama.

Wulan : hi-ihh.. enak banget tidurnya? Riko, hei Riko! Hei bangun ih. Bangun, bangun udah sore tau! Kamu udah bikin PR nya belum?

Riko : ho-oh.. kayaknya udah deh.

Wulan : ohh.. udah sholat belum?

Riko : astaghfirullah. Belum kak.

Wulan : ayo cepetan, buruan sana!

Riko : i-iya kak.

Episode Astaghfirullah Aku Lupa

$$
3: 44-4: 11
$$

Berikut penjelasan konteks tuturan tersebut. Konteks melibatkan tokoh Riko dan Kak Wulan. Mengingat waktu semakin sore, Kak Wulan datang lagi menghampiri Riko di kamarnya untuk menagih PR. Kak Wulan masuk kamar membangunkan Riko. Intonasi yang dipakai kak Wulan terdengar meninggi saat berusaha membangunkan Riko untuk sholat. Berdasarkan konteks tuturaan tersebut tuturan masuk dalam bentuk tindak tutur direktif perintah dengan maksud menyuruh mitra tutur. Konteks kelima pada episode ini melibatkan tiga tokoh yaitu Riko dan kak Wulan. Dialog berjumlah 6 dan terdiri dari 5 ko-teks. Bentuk tindak tutur direktif perintah dan nasihat yang dituturkan oleh tokoh Wulan. Konteks ini berdurasi dari menit 3:44 sampai 4:11.

Konteks keenam pada episode ini melibatkan 4 tokoh yaitu Riko, Qiio, Wulan, dan Bunda. Berjumlah 10 dialog dan 9 ko-teks. Durasi konteks dari menit 5:11 sampai 6:11. Bentuk tindak tutur yang ada dalam konteks ini meliputi bentuk direktif menasehati dan perintah. Tindak tutur menasehati dituturkan oleh tokoh Bunda dan bentuk perintah dituturkan oleh tokoh Bunda dan Wulan. Konteks ketujuh pada episode ini melibatkan tokoh Qiio, dan Bunda. Konteks ini terdiri dari 5 dialog dengan 5 ko-teks. Bentuk tindak tutur yang digunakan yaitu direktif dengan fungsi permintaan (Bunda) dan menasehati (Qiio).

Pada episode Pantang Menyerah sebagai data ketiga dalam penelitian ini terdiri dari 63 dialog yang melibatkan tokoh utama Riko, Qiio sebagai sahabatnya, tokoh Wulan sebagai kakaknya, tokoh Bunda sebagai ibu, dan tokoh Ayah. Episode ini berdurasi 9 menit 22 detik ada pada Season 02. Amanat yang ingin disampaikan pada episode ini yaitu pentingnya untuk tidak mudah menyerah. Latar waktu yang digunakan pada episode tersebut berjumlah tiga yaitu pagi, siang, dan sore hari. Episode ini terdiri dari 10 buah konteks 
dengan total 57 ko-teks. Berikut uraian konteks yang terdiri dari 1) perbincangan hangat antara Ayah dengan Riko, 2) Riko masih ngantuk, 3) nasihat Ayah pada Riko, 4) Riko mendapat kejutan sepeda baru, 5) perjanjian belajar sepeda, 6) Riko menepati janji, 7) Riko menyiram tanaman, 8) Ayah mengajak Riko belajar sepeda, 9) motivasi dari Ayah, 10) latihan belajar sepeda bersama Ayah. Episode ini peneliti menemukan bentuk tindak tutur asertif 2, direktif sebanyak 8, dan komisif sebanyak 2.

Pada episode Pagi Yang Indah sebagai data keempat dalam penelitian ini terdiri dari 34 dialog yang melibatkan tokoh utama Riko, Qiio sebagai sahabatnya,tokoh Wulan sebagai kakaknya, tokoh Bunda sebagai ibu. Episode ini berdurasi 7 menit 45 detik ada pada Season 02. Amanat yang ingin disampaikan pada episode ini yaitu keberkahan waktu subuh dan nikmatnya bangun pagi. Latar waktu yang digunakan pada episode yaitu pagi hari. Episode ini terdiri dari 5 buah konteks dan 31 ko-teks. Berikut uraian konteksnya, 1) Bunda menasihati Riko yang masih ngantuk, 2) memahami sikap Jago, 3) Riko mempertanyakan Qiio yang tak pernah makan, 4) hakikat makhluk ciptaan Allah, 5)Riko meledeki Ayam Jago. Peneliti berhasil menemukan bentuk tindak tutur asertif 7, dan bentuk direktif sebanyak 4 .

Riko : Tapi aku liat, kamu gak pernah makan Qiio.

Qiio : ahaha. Aku robot, Riko. Cara kerja tumbuh robot berbeda dengan cara kerja tumbuh Riko. Tubuh Qiio memproses cahaya sinar matahari menjadi energi. Tapi, Riko tau gak, ada beberapa makhluk hidup yang diciptakan bertahan untuk tidak makan. Tidak hanya berhari-hari, tapi bahkan ada yang kuat tidak makan hingga berbulan-bulan bahkan bertaun-taun.

Riko : loh kok bisa?

Qiio : haha.. ya bisa aja Riko. Itulah kebesaran Allah. Dengan menciptakan makhluk yang beraneka ragam, dari yang sangat besar sampe yang sangat kecil. Dari yang terlihat hingga tidak bisa dilihat oleh mata. Bahkan manusia saja diciptakan berbeda-beda. Semua itu bisa dengan mudah Allah ciptakan. Untuk menunjukkan Allah maha pencipta dan maha kuasa.

Riko : masyaAllah. Ohh, gitu.

\section{Episode Pagi Yang Indah}

$$
\text { 4:34 - 5:38 }
$$

Konteks tersebut merupakan konteks ketiga dari episode Pagi Yang Indah. Bentuk tindak tutur yang digunakan pada tuturan tersebut adalah bentuk asertif yaitu maksud menceritakan dan meyakinkan. Tuturan tersebut dituturkan oleh tokoh Qiio. Tokoh yang terlibat dalam konteks ini adalah Riko dan Qiio. Tuturan terjadi di halaman rumah pada pagi hari. Qiio berperan sebagai penutur dan Qiio sebagai mitra tutur. Konteks tuturan tersebut dapat dijelaskan sebagai berikut. Riko mempertanyakan Qiio yang tak pernah makan. Qiio menjelaskan alasannya bahwa dirinya robot. Suasana tergambar keakraban seorang sahabat.

Pada episode Hujan sebagai data kelima dalam penelitian ini terdiri dari 44 dialog yang melibatkan tokoh utama Riko, Qiio sebagai sahabatnya, tokoh Wulan sebagai kakaknya, tokoh Bunda sebagai ibu, dan tokoh Ayah. Episode ini berdurasi 8 menit ada pada Season 02. Amanat yang ingin disampaikan pada episode ini yaitu proses terjadinya hujan. Latar waktu yang digunakan pada episode yaitu siang, sore, dan malam hari. Episode ini terdiri dari 6 buah konteks dan 36 ko-teks. Berikut uraian konteksnya, 1) menunggu hujan reda, 2) Riko asyik hujan-hujanan, 3) ucapan terima kasih Riko pada Bunda, 4) penjelasan gambaran proses terjadinya hujan, 5) Sekeluarga heran melihat Ayah kehujanan, 6) kak Wulan mengajak Riko angkat jemuran. Episode ini berhasil ditemukan bentuk tindak tutur asertif 3, direktif sebanyak 9, dan bentuk ekspresif 1.

Pada episode Jangan Marah sebagai data keenam dalam penelitian ini terdiri dari 34 dialog yang melibatkan tokoh utama Riko, Qiio sebagai sahabatnya,tokoh Wulan sebagai kakaknya, tokoh Bunda sebagai ibu. Episode ini berdurasi 6 menit 2 detik ada pada Season 01. Amanat yang ingin disampaikan pada episode ini yaitu emosi dan marah harus bisa dikendalikan. Latar waktu yang digunakan pada episode yaitu siang menjelang sore hari. Episode ini terdiri dari 7 konteks dengan 30 ko-teks. Berikut uraian konteksnya, 1) balap lari antara Riko dan Qiio, 2) teguran untuk kecurangan Riko, 3) Riko kecewa, 4) Qiio mengunduh emosi 
manusia, 5) lomba lari ke-2, 6) Qiio marah pada Riko, 7) Qiio ketahuan mengunduh emosi manusia. Episode ini ditemukan beberapa bentuk tindak tutur meliputi, tindak tutur asertif 1, dan direktif sebnayak 6 .

Riko : adududuhh.. subhanallah, Qiio lobet kak.

Wulan : ha? Qiio mengalami over hit, Riko? Panasnya berlebih, itu yang membuat batrenya cepat drop.

Riko : kemarin-kemarin gak pernah kayak gini?

Wulan : subhanallah, siapa yang menginstal aplikasi emosi ke Qiio? Hemm.. sebelum kamu punya aplikasi emosi marah, sedih, kamu baik-baik aja Qiio. Batraimu tahan lama. Tapi, setelah kenal perasaan marah, disitu masalahnya. Kemarahanmu memakan daya batraimu, sehingga cepat lobet. Itu sebabnya Rasulullah mengingatkan "jangan marah, maka bagimu surga"

Riko : manusia juga begitu, kak?

Wulan : iya. Itu sebabnya orang pemarah itu cepat tua. Cepet lobet!

Episode Jangan Marah

$$
4: 44-5: 28
$$

Konteks ketujuh dalam episode jangan marah ini adalah persoalan Qiio yang ketahuan mengunduh emosi marah. Dalam konteks tersebut melibatkan dua tokoh yaitu Riko dan kak Wulan. Dialog terhitung sebanyak 6 dan terdiri dari 6 ko-teks. bentuk tindak tutur yang digunakan pada konteks tersebut yaitu tuturan direktif fungsi menasehati dan tuturan dengan maksud mengkritik yang diujarkan oleh tokoh Wulan dan Riko sebagai mitra tuturnya. Konteks tuturan tersebut dapat dijelaskan sebagai berikut. Riko mendekati Qiio. Disusul Kak Wulan lari menghampiri Qiio yang tergeletak di tanah dan terkejut penuh dengan tanya. Kak Wulan membuka batrai Qiio dan mencabut instal emosi. Suasana dalam konteks tersebut tergambar begitu menegangkan. Kak Wulan bertanya-tanya sebab Qiio bisa tergeletak tak berdaya seketika. Latar yang ada dalam konteks tersebut jelas pada waktu sore hari di halaman rumah. tuturan melibatkan dua tokoh yaitu Riko dan tokoh Kak Wulan. Ekspresi yang tergambar yaitu bingung yang ada pada tokoh Kak Wulan. Pada konteks tersebut, tokoh menggunakan dua bahasa asing seperti arab dan inggris yang diucapkan oleh tokoh Kak Wulan.

Pada episode Ayo Tumbuh ke Atas sebagai data ketujuh dalam penelitian ini terdiri dari 18 dialog yang melibatkan tokoh utama Riko, Qiio sebagai sahabatnya, tokoh Bunda sebagai ibu. Episode ini berdurasi 6 menit ada pada Season 01. Amanat yang ingin disampaikan pada episode ini yaitu rahasia di balik tingginya seseorang. Latar waktu yang digunakan pada episode yaitu siang menjelang sore hari. Episode ini terdiri dari 4 konteks dengan 16 ko-teks. Berikut uraian konteksnya, 1) Riko mencari bola basket, 2) kak Wulan menyuruh Riko minum susu, 3) Riko dan Qiio bermain basket, 4) manfaat rutin minum susu. Bentuk Tindak tutur pada episode ini terdiri dari 1 tuturan asertif, 4 tuturan direktif, dan 1 tuturan komisif.

Bunda : lagi main apaan sih kalian? Ayo susunya diminum dulu.

Riko : asyikk.. bismillah. Hem, enakk! Riko, kenapa sih kita harus minum susu setiap hari?

Qiio : ini jawabannya. Susu merupakan minuman yang sehat bagi tubuh kita. Dapat membantu pemulihan tubuh saat proses fungsi metabolisme tubuh. Kandungan protein pada susu, terbukti mampu membentuk sel atau jaringan baru sehingga proses pemulihan badan secara optimal. Susu juga kaya akan kalsium yang sangat baik bagi pertumbuhan gigi. Mengkonsumsi susu setiap hati juga sangat baik agar tubuh menjadi kuat dan sehat. Serta bertumbuh tinggi.

Qiio : masyaAllah. gitu?

Bunda : makanya, harus rajin minum susu agar tumbuhnya ke atas.

Riko : iya deh. Mulai sekarang, Riko minum susu setiap hari. Biar tumbuh sehat dan kuat.

Episode Ayo Tumbuh Ke Atas

2:55-4:08

Konteks ini merupakan konteks keempat pada episode Ayo Tumbuh Ke Atas. Tuturan melibatkan tiga tokoh yaitu Riko, Bunda, dan Qiio. Dalam konteks tersebut terdiri dari 6 dialog dan 6 ko-teks. Durasi konteks 
ada pada menit 2:55 sampai 4:08. Latar yang ada pada konteks yaitu di sofa ruang tamu dan waktu menunjukkan sore hari. Konteks tuturan tersebut dapat dijelaskan sebagai berikut. Bunda berjalan mendekati Riko dan Qiio di halaman samping rumah sambil memegang segelas susu di tangannya. Riko langsung minum susu. Qiio menjelaskan khasiat minum susu bagi tubuh. Tuturan pada konteks tersebut menggunakan bentuk tindak tutur direktif perintah yang dituturkan oleh tokoh Bunda. Dan bentuk tindak tutur direktif nasihat juga digunakan oleh tokoh Bunda dengan maksud menganjurkan pada Riko sebagai lawan tuturnya.

Episode lebih baik memaafkan sebagai data kedelapn dalam penelitian ini terdiri dari 48 dialog yang melibatkan tokoh Riko, Qiio, Bunda, dan Wulan. Amanat yang hendak disampaikan pada episode ini adalah hebatnya memaafkan dapat membuat bahagia. Latar yang ada pada episode ini yaitu siang menjelang sore hari di kamar Riko. Episode ini terdiri dari 8 konteks dengan 45 ko-teks. Berikut uraian konteksnya, 1) jeritan sakit luka Riko, 2) Qiio membantu obati luka Riko, 3) Riko sibuk mencari pelindung tubuh, 4) Riko memakai pelindung tubuh, 5) Wulan mencemaskan Riko, 6) Riko bercerita pada kak Wulan, 7) kak Wulan bangga pada Riko setelah mengetahui surat dari Arya, 8) Qiio bangga pada Riko. Bentuk tindak tutur pada episode ini ditemukan tuturan direktif sebanyak 5 , tuturan asertif sebanyak 6 , komisif terdapat 1 , dan ekspresif berjumlah 5.

Qiio : Riko ngapain ya? Hep, hai, hap, Riko kamu cari apa si?

Riko : lagi cari body protector aku.

Qiio : hah, body protector?

Riko : iya, body protector. Buat ngelindungin aku.

Qiio : aha! Kamu emang hebat, Riko.

Riko : yang hebat itu Bunda. Karena Bunda bilang, jadi anak itu harus banyak akal.

Qiio : iya deh. Yaudah kalo gitu, aku bantu ya?

\section{Episode Lebih Baik Memaafkan}

$1: 35-2: 16$

Konteks pada tuturan tersebut merupakan konteks ketiga pada episode lebih baik memaafkan. Konteks tuturan tersebut dapat dijelaskan sebagai berikut. Riko turun dari kasur dan menghampiri kardus di depannya sambil mengacak-acak. Qiio berusaha menangkap lemparan benda Riko sampai terjatuh di kasur. Lalu Qiio membantu Riko yang terlihat kebingungan mencari suatu benda. Pada konteks tersebut terlihat jelas tokoh Riko menggunakan dua bahasa yaitu mencampurkan bahasa inggris ke dalam tuturannya. Latar pada konteks tersebut menggambarkan waktu siang hari di kamar Riko. Bentuk tindak tutur deklaratif dituturkan oleh tokoh Qiio. Dalam tuturan tersebut melibatkan hanya dua tokoh yaitu Riko dan tokoh Qiio.

Dari hasil temuan yang di peroleh, penelitian ini berhasil mengungkap jumlah teks, ko-teks, dan konteks. Dalam penemuan konteks, komponen konteks berhasil mendeskripsikan latar, tujuan, maksud, jenis tutran. Beberapa komponen pembangun konteks tersebut dapat ditafsirkan bahwa setiap terbentuknya konteks tidak harus mengungkap keseluruhan. Jika memang di dalamnya tidak menjawab aspek tersebut, gambaran konteks akan jelas meskipun hanya mmapu menjawab sebagiannya. Karena hakikat konteks adalah berupa situasi atau latar dalam sebuah komunikasi sebagai alasan terjadinya suatu percakapan.

Hasil penelitian menunjukkan bahwa teks, ko-teks, dan konteks sangat berpengaruh terhadap ungkapan makna atau maksud dalam suatu pertuturan. Selain itu, untuk menafsirkan bentuk tindak tutur dari tuturan seseorang perlu adanya disiplin dari ketiga aspek tersebut. Begitu pentingnya konteks dalam kegiatan komunikasi baik langsung maupun tidak secara langsung. Proses kelancaran berkomunikasi akan baik jika petutur dengan mitra tutur dapat saling memahami konteks. Hal ini juga di dukung oleh penelitian (Rahmawati, 2016).

Sesuai dengan pendapat (Zainurrahman, 2011) bahwa teks adalah seperangkat unit bahasa baik lisan maupun tulisan, dengan ukuran tertentu, makna tertentu, serta tujuan tertentu. Penanda teks dalam penelitian ini berasal dari bahasa lisan yang dituturkan melalui dialog para tokoh film Riko The Series. Berdasarkan teori 
3359 Analisis Tindak Tutur pada Film Riko The Series (Kajian Pragmatik) melalui Teks, Ko-teks, dan Konteks Foottriani Azziz, Suntoko, Wienike Dinar Pratiwi

DOI: https://doi.org/10.31004/edukatif.v3i5.1302

Hymes (Wibowo, 2020) secara utuh yang membagi komponen konteks dalam analisis teks, penelitian ini tidak ditemukan secara sempurna dalam arti bahwa hasil penelitian hanya mencakup beberapa dari komponen tersebut. Akan tetapi hal tersebut tidak mengurangi keutuhan penelitian ini. Konteks yang tergambar tergambar dengan jelas berkat aspek penunjang sebuah film yaitu sinematografi yang meliputi setting, properti, efek, gambar, dan audio.

\section{KESIMPULAN}

Dari hasil data yang diperoleh tersebut dapat memberi gambaran bahwa dalam berkomunikasi perlu adanya pemahaman bersama antara penutur dan mitra tutur. Maksud dan tujuan tuturan sangat erat kaitannya dengan konteks suatu tuturan. Pesan dapat tersampai dengan baik melalui bahasa yang baik. Begitu pentingnya peran konteks sangat diperlukan dalam sebuah komunikasi. Tidak hanya konteks saja, namun teks dan koteks juga dibutuhkan dalam mendeskripsikan makna dan tujuan tuturan. Ketiganya menjadikan unsur pembangun sebuah wacana baik lisan maupun bersifat tulisan. Dalam penelitian ini peneliti berhasil menemukan sebanyak 52 konteks, 295 ko-teks, dari total 326 dialog atau teks. Berkat ketiga aspek tersebut, peneliti juga menemukan empat bentuk tindak tutur meliputi asertif, direktif, komisif, dan ekspresif. Keempat bentuk tuturan tersebut terkumpul sebanyak 76 total bentuk tuturan dari delapan episode. Tindak tutur direktif yang mendominasi dengan total 46.

\section{UCAPAN TERIMA KASIH}

Puji serta syukur saya panjatkan kepada Allah SWT yang telah memberikan rahmat dan hidayahnya sampai penelitian ini selesai. Tanpa mengurangi rasa hormat, saya ucapkan terima kasih yang sebesarbesarnya kepada kedua dosen pembimbing yang telah memberikan ilmu dan motivasinya. Beserta keluarga besar, kedua orang tua saya yang selalu memberikan semangat sampai titik ini.

\section{DAFTAR PUSTAKA}

Achsani, F. (2019). Tindak Tutur Direktif Dan Implikatur Konvensional Dalam Wacana Meme Dilan. Imajeri: Jurnal Pendidikan Bahasa Dan Sastra Indonesia, 1(2), 1-10.

Arikunto, S. (2013). Prosedur Penelitian Suatu Pendekatan Praktik.

Asriningsih, N. (2020). Tindak Tutur Ilokusi Dan Perlokusi Dalam Novel Dua Garis Biru Karya Gina S. Noer. Universitas Islam Sultan Agung Semarang.

Kurnia, R., \& Solfiah, Y. (2018). Pengaruh Media Pensil Karakter Animasi Upin Dan Ipin Terhadap Kemampuan Menulis Anak. Jurnal Pendidikan Usia Dini, 12(2), 341-350.

Latifah, A. (N.D.). N.(2018). Tindak Tutur Direktif Pada Dialog Film Surga Yang Tak Dirindukan 2 Pada Siswa Kelas XI SMA. Surya Bahtera, 6(53), 419-428.

Mahsun, M. S. (2014). Metode Penelitian Bahasa Metode Penelitian Bahasa: Tahapan Strategi Metode Dan Tekniknya. Jakarta: Raja Grafindo Persada.

Makhroyani, Y. (2012). TA: Pembuatan Film Animasi 2D Dalam Cerita Aryo Blitar Dengan Teknik Rigging $3 D$. STIKOM Surabaya.

Moleong, L. J. (2016). Metodologi Penelitian Kualitatif Edisi Revisi.

Prayitno, H. J. (2017). Studi Sosiopragmatik. Muhammadiyah University Press.

Rahma, A. N. (2018). Analisis Tindak Tutur Ilokusi Dalam Dialog Film Animasi Meraih Mimpi. Jurnal 
3360 Analisis Tindak Tutur pada Film Riko The Series (Kajian Pragmatik) melalui Teks, Ko-teks, dan Konteks Foottriani Azziz, Suntoko, Wienike Dinar Pratiwi

DOI: https://doi.org/10.31004/edukatif.v3i5.1302

Surabaya: Skriptorium, 2(2), 13-24.

Rahmawati, I. Y. (2016). Analisis Teks Dan Konteks Pada Kolom Opini "Latihan Bersama Al Komodo 2014" Kompas. Jurnal Dimensi Pendidikan Dan Pembelajaran, 4(1), 49-57.

Rahmayanti, R. D., Yarno, Y., \& Hermoyo, R. P. (2021). Pendidikan Karakter Dalam Film Animasi Riko The Series Produksi Garis Sepuluh. Kembara: Jurnal Keilmuan Bahasa, Sastra, Dan Pengajarannya (EJournal), 7(1).

Rahzanie, R. D. (2015). Analisis Pragmatik Wacana Stand Up Komedi Mongol Kajian Konteks Dan Ko-Teks. Prosiding Prasasti, 199-202.

Riyanto, S. (2015). Tindak Tutur Perlokusi Dalam Iklan Radio Di Kota Kebumen. Universitas Negeri Semarang.

Sudaryanto, S. (2015). Metode Dan Aneka Teknik Analisis Bahasa. Yogyakarta: APPTI.

Sugiyono. (2018). Metode Penelitian Pendidikan:(Pendekatan Kuantitatif, Kualitatif Dan $R \& D$ ). Alfabeta.

Wibowo, S. E. (2020). The Practice Of Adu Rasa, Angon Rasa, And Njaga Rasa In The Speech Act Of Javanese Kiai: An Ethnopragmatic Study. Humanus, 19(1), 136-149.

Widayanti, S. R., \& Kustinah, K. (2019). Analisis Pragmatik Pada Fungsi Tindak Tutur Dalam Film Karya Walt Disney. PRASASTI: Journal Of Linguistics, 4(2), 180-185.

Zainurrahman, S. S. (2011). Menulis: Dari Teori Hingga Praktik. Bandung: Alfabeta. 